\title{
Capital Structure and Firm's Growth in Relations to Firm Value at Oil and Gas Companies Listed in Indonesia Stock Exchange
}

\author{
M. Daffa Hammam Syaifulhaq \\ Faculty of Economics and Business \\ Universitas Padjadjaran \\ Aldrin Herwany \\ Faculty of Economics and Business \\ Universitas Padjadjaran \\ Layyinaturrobaniyah \\ Faculty of Economics and Business \\ Universitas Padjadjaran
}

\begin{abstract}
The value of the firm is an investor's perception of the firm's success that is often associated with the performance of its shares. The height of the firm's value indicating that the market believes in not only the firm's present condition but also in the firm's prospect. Several factors are thought to affect the value of the firm, like funding decisions, dividend policy, stock decision, firm growth and firm size. This study aims to see whether there is any effect of capital structure and the level of firm growth on firm value. The sample used in this study was six oil and gas companies listed on the Indonesia stock exchange in the 2013-2017 period. Regression analysis is built on an unbalanced panel data set. The results of this study indicate that the capital structure proxied by the variable debt to equity ratio has a negative coefficient direction but is not significant to the firm's value, while the growth rate has a positive effect coefficient direction on the firm's value but also not significant.
\end{abstract}

Keywords: Debt to Equity Ratio; Asset Growth; Return on Equity; Price to Book Value.

\section{Introduction}

A firm must be able to improve its performance, which is designated by the level of increased productivity of the firm supported by management's commitment to the welfare of all interested parties to keep surviving in an increasingly competitive business environment. Improvement of firm productivity and performance is closely related to management's ability to determine its funding policy. The essence of the funding policy is to choose to use whether debt or equity to fund investment and firm operations. Management's ability and flexibility in choosing alternative among funding decisions is very limited in situations while the exchange rate has increased.

The value of a firm is determined by the level of profitability and growth of the firm, both of which are very dependent on the company's strategy. The company's strategy is implemented through policies related to operational activities, funding, and investment. Based on the capital structure theory, it is stated that funding policy is how companies determine the capital structure that can optimize the value of the company and minimize the cost of capital. Firm value can be interpreted as the shareholders' expectation of the value of their investment (market value of equity) and or expectations of the total value of a company (market value of equity plus the market value of debt) so that the value of the company will reflect management's capability in determining its target capital structure, capability management in using its assets effectively and efficiently, and operational management capabilities in streamlining the production and distribution processes. Indonesia has a 
geological basin diversity that continues to offer significant potential for oil and gas. Indonesia has 60 sedimentary basins, 36 of which have already been thoroughly explored in Western Indonesia. Fourteen of these are oil and gas producers. Thirty-nine tertiary and pretertiary basins show rich promise in hydrocarbons in underexplored areas of Eastern Indonesia. About $75 \%$ of exploration and production is located in Western Indonesia. The four oil-producing regions are Sumatra, the Java Sea, East Kalimantan and Natuna. The three main gas-producing regions are East Kalimantan, South Sumatra and Natuna.

Over the past decade, Indonesia's crude oil production declined due to the natural maturation of oil field production combined with a slower reserve replacement rate and decreased exploration/investment. Indonesia's oil production was approximately 804 Thousand Barrels of Oil Per Day (MBOPD) during 2017, a slight decrease from 831 MBOPD in 2016. The 2018 target for daily oil lifting is 800 MBOPD, a slight decrease from the previous year, while the 2018 target for gas production is equivalent to 1,200 Thousand Barrels of Oil Equivalent per day (MBOEPD). However, with few significant oil discoveries in Western Indonesia over the past ten years, Indonesia still relies on mature oil fields that continue to decline in production, thus encouraging contractors to explore the boundaries and deep-sea areas of Eastern
Indonesia. Indonesia's gas production represents 60 percent of the country's total oil and gas production, further demonstrating the importance of gas. It was estimated that this portion would rise to $70 \%$ in 2020 and $86 \%$ in 2050. Similar to oil, however, gas reserves are forecast to decline, slowly but surely with current proven reserves are estimated at 101 TCF. Following the depletion of some major fields, such as the gas-rich Mahakam block, it is estimated that reserves will decline to $96 \mathrm{TCF}$ by 2020 unless significant new proven reserves are discovered.

Over the past few decades, Indonesia's economic growth has relied heavily on the oil and gas sector. However, in line with the decline in oil production and reserves, the contribution of the oil and gas sector to government revenues has also declined significantly in recent years. Thus, government revenue from the oil and gas industry fell by nearly 80 percent from Rp 216 trillion in 2014 (14 percent of government revenue) to $\mathrm{Rp} 44$ trillion in 2016 (2.8 percent of government revenue), before rising oil prices improved the contribution of the oil and gas sector in 2017. A press release from the Ministry of Energy and Mineral Resources (MoEMR) indicated an unaudited state income of Rp 138 trillion from the oil and gas sector in 2017, which was $117 \%$ of the target. The table below shows the contribution of the oil and gas sectors (in Trillion Rupiah)

Table 1. Oil and Gas Contribution to State Revenue

\begin{tabular}{cccc}
\hline Year & $\begin{array}{c}\text { State Revenue } \\
\text { (in Trillion Rupiah) }\end{array}$ & $\begin{array}{c}\text { Oil and Gas Revenue } \\
\text { (in Trillion Rupiah) }\end{array}$ & $\begin{array}{c}\text { Percentage of } \\
\text { Contribution }\end{array}$ \\
\hline 2005 & 494 & 104 & $21.05 \%$ \\
2006 & 636 & 158 & $24.84 \%$ \\
2007 & 706 & 125 & $17.71 \%$ \\
2008 & 979 & 212 & $21.65 \%$ \\
2009 & 847 & 126 & $14.88 \%$ \\
2010 & 992 & 153 & $15.42 \%$ \\
2011 & 1205 & 193 & $16.02 \%$ \\
2012 & 1338 & 206 & $15.38 \%$ \\
2013 & 1438 & 204 & $12.56 \%$ \\
2014 & 1538 & 217 & $14.11 \%$ \\
2015 & 1508 & 78 & $4.46 \%$ \\
2016 & 1555 & 44 & $2.84 \%$ \\
2017 & 1396 & 70 & $4.99 \%$ \\
2018 & 1895 & 80 & $4.24 \%$ \\
\hline
\end{tabular}

Source: PWC Oil and Gas in Indonesia Investment and Taxation Guide 
While the investment and contribution value of the oil and gas industry is declining, oil and gas companies show a volatile debt to equity ratio (DER) throughout the 2013-2017 period. As can be seen in the above graph, the DER for ESSA and PKPK tend to increase during the period. Meanwhile, other companies such as RUIS, ELSA, and ARTI had shown a decreasing trend in their DER. There is also a company whose DER had both increased and decreased throughout the period, which is MEDC. From 2013 to 2015, the DER for MEDC was increasing, but later on, it started to decrease from 2015 to 2017. While the investment and contribution value of the oil and gas industry is declining, oil and gas companies show a volatile debt to equity ratio (DER) throughout the 2013-2017 period. As can be seen in the above graph, the DER for ESSA and PKPK tend to increase during the period. Meanwhile, other companies such as RUIS, ELSA, and ARTI had shown a decreasing trend in their DER.

There is also a company whose DER had both increased and decreased throughout the period, which is MEDC. From 2013 to 2015, the DER for MEDC was increasing, but later on, it started to decrease from 2015 to 2017. Although the productivity and contribution of the oil and gas sector to government revenues declined, based on Figure 1 showed that the debt ratio of companies engaged in the sector tends to increase for the 2015-2017 period, like PT Surya Eka Perkasa, Tbk. (ESSA) and PT Perdana Karya Perkasa, Tbk. (PKPK). Meanwhile, other companies such as PT Radiant Utama Interinsco, Tbk. (RUIS), PT Elnusa, Tbk. (ELSA), and PT Ratu Prabu Energi, Tbk. (ARTI) had shown a downward trend in the debt ratio. Meanwhile, PT Medco Energi Internasional, Tbk. (MEDC) in 20132015 experienced an increase in the debt ratio, while in 2015-2017, the debt ratio began to decline. Meanwhile, other companies such as RUIS, ELSA, and ARTI had shown a decreasing trend in their DER. There is also a company whose DER had both increased and decreased throughout the period, which is MEDC. In 2013 to 2015, the DER for MEDC was increasing, but later on, it started to decrease from 2015 to 2017

Figure 1. Oil and Gas Industry Debt to Equity Ratio

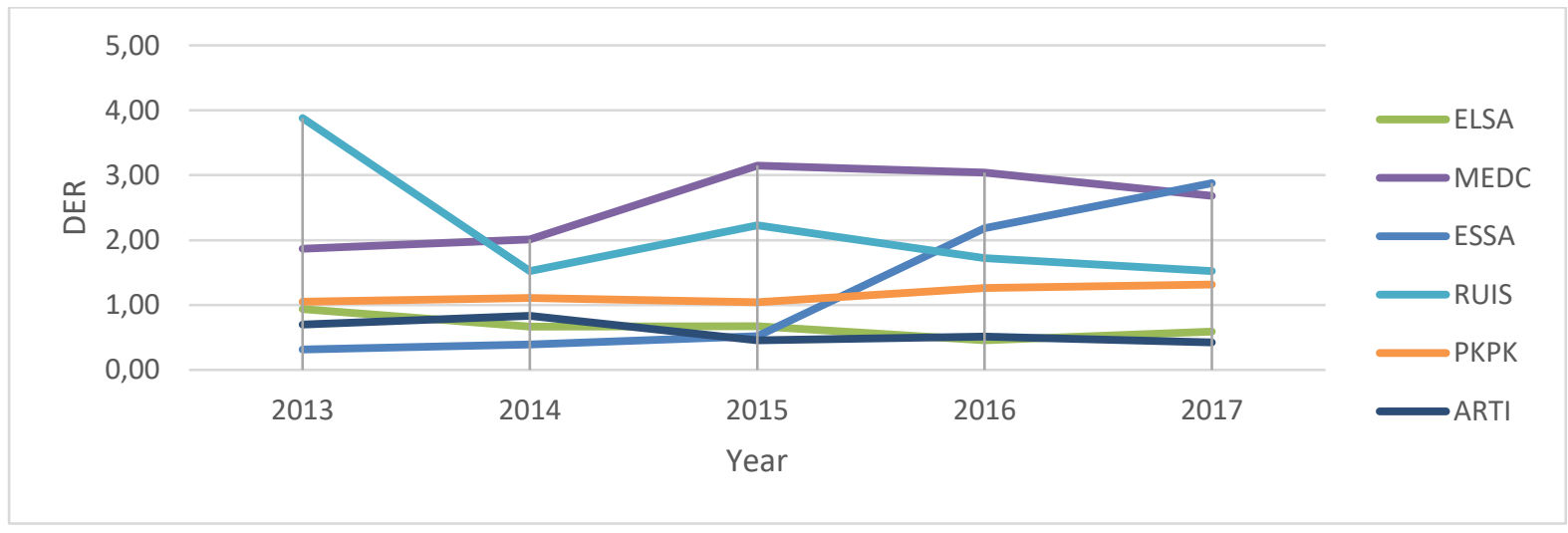

Source: Financial report

While the investment and contribution value of the oil and gas industry is declining, oil and gas companies show a volatile debt to equity ratio (DER) throughout the 2013-2017 period. As can be seen in the above graph, the DER for ESSA and PKPK tend to increase during the period. Meanwhile, other companies such as RUIS, ELSA, and ARTI had shown a decreasing trend in their DER. There is also a company whom DER had both increased and decreased throughout the period, which is MEDC. In 2013 to 2015, the DER for MEDC was increasing, but later on it started to decrease during 2015 to 2017.

In determining policies related to capital structure, the company must pay attention to relevant factors in accordance with the 
characteristics of the industry. Decisions regarding capital structure involve determining the composition of debt and equity that will be used to fund investments made by companies. The right capital structure decision will be able to generate an optimal capital structure, namely the capital structure that will minimize the cost of capital and maximize the value of the firm. Several previous studies in several countries have proved this. Financing policies (capital structure) does not directly improve the asset's productivity, financial performance, or the value of the firm. Good funding policy will increase the value of the firm if management capabilities(activities) in investment and management (activities) operating companies are also good. Is this situation applies to the oil and gas industry firms in Indonesia? Is funding policies that make up the capital structure (financial activity) affects the investment activity, operating, asset productivity, financial performance, and value of open oil and gas industry-standard enterprises in Indonesia?

\section{Literature Review And Hypothesis Development}

Firm Value

The firm's original theory was based on the assumption that the firm's intention or purpose is to maximize current revenue (short-term revenue). Companies are often sacrificing their short-term profits; however, based on observations, to increase future earnings. Because both the short-term and long-term benefits are significant, the theory of companies (the firm's theory) is now assumed that the intention or the primary goal of the firm is to maximize the wealth for all involved parties and the value of the firm. It reflected in all expected corporate profits in the future in the present value. The firm's value depends not only on the ability to generate cash flow but also on the acquired firm's operational and financial features.

According to the firm's theory, the firm's primary purpose is to maximize wealth or business value (Salvatore, 2005). Maximizing the firm's value is as important as maximizing shareholder wealth as the firm's ultimate goal
(Euis \& Taswan, 2002). According to Husnan (2000), the firm's value is willing to pay the price if the firm was sold to potential buyers. Meanwhile, according to Keown (2004), the firm's value is the market value of outstanding companies' debt and equity securities. The firm's value is the investor's perception of the firm's level of success that is often linked to stock prices. The high price of the stocks affects the value that too high for the firm. According to Brigham and Houston (2001), several approaches to market value assessment ratio analysis consisted of price-earnings ratio (PER), price-book value ratio (PBVR), market book ratio (MBR), dividend yield ratio, and dividend payout ratio (DPR) are available. PBV in this study measures the value of the firm. The stock price-to-book value ratio (PBV) indicates the level of the ability of the firm to create value relative to the amount of capital invested. High PBV reflects a higher stock price than the value of the book per share. The higher the stock price, the more the firm succeeds in creating value for shareholders.

The firm's success creates value that giving hope to shareholders in the form of higher profit anyway (Sartono, 2001), simply states that the price to book value (PBV) is the ratio of the market (market ratio) which is used to measure the performance of stock market prices to value book. This ratio is calculated by the following formula (Robert, 1997):

$$
\mathrm{PBV}=\frac{\mathrm{PS}}{\mathrm{BVS}}
$$

Ps is the price of the stock market and the BVS is the book value per share (book value per share). BVS is used to measure the value of shareholders 'equity on each share, and the value of the BVS is calculated by dividing total shareholders' equity by the number of shares outstanding. PBV has several advantages as follows: (1) the book's value has a relatively stable intuitive measure that can be compared to the market price. Investors lack confidence with the discounted cash flow method can be used as a price book value ratio; (2) The book value provides a consistent accounting standard for all companies. PBV can be compared against the same companies as indicative of under or overvaluation, (3) Companies with 
negative earnings, which can not be assessed using the price-earnings ratio (PER), can be evaluated using the price-book value ratio (PBV).

\section{Capital Structure}

Modern capital structure theory began in 1958 when Professor Franco Modigliani and Merton Miller (will be referred to MM) published what is known as one of the most influential financial articles ever written. With a set of very restrictive assumptions, MM proves that a firm's value is not affected by capital structure. In other words, MM's results show how a firm is financing its operations, so the capital structure is irrelevant. However, MM based its theory on several unrealistic assumptions, including the following: 1) no brokerage fees, 2) there are no taxes, 3) no bankruptcy costs, 4) the investor can borrow at the same rate with the firm, 5) investors and management are equally informed about investment opportunities in the future, 6) EBIT is not affected by the use of leverage.

Although some of the above assumptions are clearly unrealistic, a very important meaning is given to the result of MM theory. By showing the conditions under which the capital structure is irrelevant, MM also gives hints about what is needed to make the capital structure relevant that affects the firm's value. The fact that the occurrence of interest could make tax becomes deductible is causing debt to be cheaper than common stock or preferred stock. As a result, indirectly, the government will pay most of the cost of debt capital, or in any other way, debt provides tax shelter benefits. If the portion of the debt that a firm uses keeps increasing, it will affect the share price and firm value to be higher. According to the assumption behind the writings of Moddigliani-Miller, the existence of a tax can help a firm's stock price to reach its maximum value under the case when the firm is fully utilizing 100 percent debt. Companies rarely utilize debt to 100 percent in real life. The primary purpose that companies limit their debt utilization is to keep the costs associated with the bankruptcy remains low.
Based on MM's research, it is assumed that investors and managers acquire equal information about firm prospects. This condition is also known as symmetric information. However, in reality, it is often found that outside parties usually have lesser information than managers. This condition is known as asymmetric information and has a crucial influence on the optimal capital structure. To decrease excess cash flow, there are multiple options that the firm can choose to do. The first option is to redistribute the excess cash flow to shareholders through share repurchase or higher dividends. Another option is to shift the capital structure towards debt, expecting that as debt closing conditions become higher, the more disciplined the managers will be. The firm will be forced to be declared bankrupt if the debt is not covered as required. Purchases through debt, or also known as leverage buyout (LBO), is another option that firms can choose to decrease excess cash flow. Through LBO, debt will be used to provide funding for the purchase of shares of a firm, which later will be held in private.

The financial structure is defined as a way for the firm to finances its assets. It consists of stockholders' equity, short-term debt and long-term debt, which can be seen on the right side of the balance sheet. Meanwhile, capital structure is specifically comprised of permanent financing, which includes long-term debt, preferred stock, and stockholders' equity. Therefore, it can be concluded that the firm's capital structure is only a part of its financial structure. Essentially, the main concern of a firm's financing decision is to determine the source of funds used to finance the investment proposals that had been previously decided. These funds can be provided internally or externally. If the firm is internally funded, it means that the firm is utilizing its retained earnings for internal financing purposes. On the other hand, if the firm is externally funded, it means that the firm is doing external financing. There are two types of external financing, namely debt financing and equity financing. Debt financing is obtained through debts, whereas equity financing is obtained through share issuance. 
The capital structure is defined as the comparison between the amount of the firm's long-term debt with the amount of a firm's capital. One of the indicators that are often used to measure capital structure is the debt to equity ratio (DER). Total debt is the total liabilities for both short-term and long term periods. Meanwhile, total shareholders' equity is the total capital (total retained earnings and paid shares of capital) owned by the firm. Through this ratio, the structure or composition of total debt towards the total capital of the firm can be seen more clearly. If the DER is high, it means that the total debt composition is greater than the total equity, thereby generating a greater firm burden to outsiders (Robert, 1997).

\section{Firm Growth}

Growth expressed as total asset growth, describing future profitability and future growth in past asset growth (Taswan, 2003). Growth is defined as changing (decreasing or increasing) the firm's total assets. Asset growth is calculated at a particular time compared to the previous year as the percentage of asset change (Saidi, 2004). It can be explained based on the above definition that growth is the change in total assets, either in the form of increases and decreases experienced by the firm over a period (one year). Asset growth describes the growth of firm assets that will affect the profitability of companies that believe that the change in percentage of total assets is a better indicator for measuring the firm's growth (Putrakrisnanda, 2009). The ratio of asset growth or decline is used as an indicator of corporate growth. In this study, the growth of the firm is measured by the proportion of changes in assets to compare the increase or decrease in the firm's total assets.

A firm's growth rate will show how far companies will use debt as a source of funding. Companies with a high growth rate should use equity as a source of funding in conjunction with leverage to avoid the cost of agency between shareholders and the management of the firm. On the other hand, low-growth companies should use debt as a source of funding because the use of debt will require the firm to pay interest regularly. Companies with high potential growth rates tend to generate high future cash flows and high market capitalization, allowing the firm to have lower capital costs. Thus, leverage has a negative correlation with growth rate, so the higher the growth, the lower the debt-to-equity ratio, assuming other variables are constant.

\section{Capital Structure and Firm Value}

Trade-off theory explains that an increase in the debt ratio in the capital structure will increase the value of the firm by an equal amount to the tax rate multiplied by the amount of the debt (assuming the capital structure target point is not yet optimal). In their research, Solihah \& Taswan (2002) show that the debt policy has a positive but negligible effect on the firm value. The results of this study are consistent with Modigliani \& Miller's findings in 1963, which stated that the use of debt would increase shareholder value by including corporate income tax. In her research, Hasnawati (2005) shows that the decision on funding has a positive effect on firm value.

In his research, Driffield, et al. (2007) indicate that there is a significant influence in Indonesia, Korea, Malaysia on the ownership structure towards leverage (DAR) and the firm's value (Tobin'Q), but it is not significant in Thailand. The trade-off theory explains that any additional debt will increase the value of the firm if the position of the capital structure is under the optimal point. Moreover, vice versa, if the capital structure's position is above the optimum point, then any additional debt would lower the firm's value. Therefore, based on the trade-off theory, assuming that an optimal capital structure target point has not been reached, it is predicted that there will be a positive relationship to the firm's value.

\section{Firm Growth and Firm Value}

Companies with a high growth rate should use equity as a source of funding in conjunction with leverage in order to avoid the cost of agency between shareholders and the management of the firm. Meanwhile, lowgrowth firms should use debt as a source of funding because debt usage will require the firm to pay interest regularly. The firm's rapid growth will increase the need for expansion funds. The higher the need for future funding, 
the higher the desire of the firm to retain earnings. Hence, the growing firm should not distribute profits as dividends to shareholders but should use it better for expansion. It is possible to measure the potential of this growth by the amount of research and development costs. The higher the cost of R\&D means that the prospects for growth of the firm exist (Sartono, 2001: 248).

Kallapur \& Trombley (1999) stated that the realization of the growth of the firm is based on the value of the growth of the firm, which includes asset and equity growth. The firm's assets show the past decision on the use of funds or investment decisions. Assets are defined as resources that will provide the firm with the potential for future economic benefits. It can be called an asset as a resource that could generate cash inflows or reduce the ability to cash outflow. These resources are recognized as the assets of the firm. The firm would have been granted the right to use such assets in the past as a result of a transaction or exchange, and the future economic benefits can be measured, quantified with sufficient accuracy.

Growth is the impact of growth or decline in business volume on the flow of funds from the firm's operational changes (Helfert, 1997: 333). The internal and external parties expect the growth of the firm due to a good sign of growth for the firm's development. From an investor's perspective, a firm's growth is a sign that the firm has a positive aspect, and the investor would expect the investment's return rate to show proper development. Evidence found by Stulz (1990) showed that the debt ratio is positively related to the firm's value for companies facing lower growth opportunities. While the debt ratio is negatively related to the value of the firm for companies facing higher growth opportunities. The effect of the debt on the firm's value is therefore highly dependent on the existence of opportunities for growth. Sriwardany (2006) research found that the firm's growth has a direct and positive influence on stock price changes, which means that investors responded positively to information about their firm's growth, thus increasing stock price.

\section{Previous Research}

There are significant differences in the researches on the impact of capital structure on firm values. Vo (2017) in his research tells about the impact of capital structure on firm value in Vietnam finds that companies with a low leverage yield has significantly higher positive returns than the market, while Hoque (2014) tend to be on the neutral side stating that When it is seen that there is positive relationship between value of the firm and capital structure; that means- debt and equity mix is most favorable position in nature but when it is seen that there is negative relationship between value of the firm and capital structure, that means- debt and equity mix are scattered. As a result, firms are covered with high-risk position

Table 2. Previous Research Finding

\begin{tabular}{|c|c|c|c|c|c|}
\hline \multicolumn{2}{|c|}{ Positive Impact } & \multicolumn{2}{|r|}{ Neutral } & \multicolumn{2}{|c|}{ Negative Impact } \\
\hline Author and title & Result & Author and title & Result & Author and title & Result \\
\hline $\begin{array}{c}\text { Vo, X. V., \& Ellis, } \\
\text { C. (2017). An } \\
\text { empirical } \\
\text { investigation of } \\
\text { capital structure } \\
\text { and firm value in } \\
\text { Vietnam. Finance } \\
\text { Research Letters, } \\
22,90-94 . \\
\text { https://doi.org/10.1 } \\
\text { 016/j.frl.2016.10.0 } \\
14\end{array}$ & $\begin{array}{l}\text { This study finds that } \\
\text { firms with low } \\
\text { leverage yield } \\
\text { significantly higher } \\
\text { positive returns than } \\
\text { the market. }\end{array}$ & \begin{tabular}{|c|} 
Hoque, J., \\
Hossain, A., \& \\
Hossain, K. \\
(2014). Impact of \\
Capital Structure \\
Policy on Value \\
of the Firm- a \\
Study on Some \\
Selected \\
Corporate \\
Manufacturing \\
Firms Under \\
Dhaka Stock \\
Exchange. \\
Ecoforum,3 (2), \\
$77-84$.
\end{tabular} & $\begin{array}{l}\text { When it is seen that } \\
\text { there is positive } \\
\text { relationship between } \\
\text { value of the firm and } \\
\text { capital structure; that } \\
\text { means- debt and equity } \\
\text { mix is most favorable } \\
\text { position in nature but } \\
\text { when it is seen that there } \\
\text { is negative relationship } \\
\text { between value of the } \\
\text { firm and capital } \\
\text { structure, that means- } \\
\text { debt and equity mix is } \\
\text { scattered . As a result, } \\
\text { firms are covered with } \\
\text { highly risk position. }\end{array}$ & \begin{tabular}{|c|} 
Safrida, E. (2008). Eli \\
Safrida: Pengaruh \\
Struktur Modal Dan \\
Pertumbuhan \\
Perusahaan Terhadap \\
Nilai Perusahaan Pada \\
Perusahaan Manufaktur \\
Di Bursa Efek Jakarta, \\
2008. USU e- \\
Repository @ 2008. \\
Skripsi.
\end{tabular} & $\begin{array}{l}\text { Research finds that the use } \\
\text { of debt as a source of } \\
\text { corporate funding and a } \\
\text { decrease in changes in total } \\
\text { assets of the company will } \\
\text { increase the price of a } \\
\text { share of equity to a share } \\
\text { when the company reduces } \\
\text { the use of debt and despite } \\
\text { a decrease in the total } \\
\text { assets of the company, the } \\
\text { company is still able to } \\
\text { obtain funds in the capital } \\
\text { market to invest so the } \\
\text { market value of a share of } \\
\text { equity in a share will } \\
\text { increase. }\end{array}$ \\
\hline
\end{tabular}




\section{Research Hypothesis}

H1: The capital structure has a significant effect on the firm value of oil and gas firms in the Indonesia Stock Exchange.

$\mathrm{H} 2$ : The firm growth has a significant effect on the firm value of oil and gas firms in the Indonesia Stock Exchange.

\section{Methods}

This research model's parameters are estimated using a data panel regression. In the regression equation, the first model does not use dummies. While in the regression equation, the second model uses a dummy variable. Use chow test, random test, and test the Lagrange Multiplier (LM), if necessary, to select the model on the panel data. The feasibility of a model in testing the hypothesis must be tested after the selection of methods and the establishment of regression models.

Secondary data is the data used in this research. Secondary data, according to
Malhotra (2010), is data obtained indirectly or through another party, or historical reports compiled in the published or not record. The data used in this study are the financial performance data obtained from 9 oil and gas companies on the Indonesia Stock Exchange (IDX) website from the financial report of the firm.

The population is a collection of all the members of the object being observed. The population in this study are all oil and gas firms listed on the Indonesian Stock Exchange of Indonesia Capital Market Directory (ICMD). The total population of nine oil and gas companies. While the sample is a collection of some of the members of the object being studied.

The purposive sampling technique used in this research, the sample was selected by using certain considerations adapted to the purpose of research (Ferdinand, 2006). Based on these criteria, the number of samples from this study described in the table below:

Table 3. Firm Sample Criteria

\begin{tabular}{llc}
\hline No. & Sample Characteristics & Number \\
\hline 1 & Oil and gas firm listed on the Indonesia Stock Exchange Year 2013-2017 & 9 \\
2 & $\begin{array}{l}\text { Oil and gas companies that publish the complete financial reports of the } \\
\text { Year 2013-2017. }\end{array}$ & 8 \\
$3 \quad$ Oil and gas companies that have a positive DER of the Year 2013-2017. & 6 \\
\hline Total Sample Research (Oil and Gas Firm) & 6 \\
\hline
\end{tabular}

The analytical method used to test the effect of capital structure (X1), the firm's growth (X2), to firm value $(\mathrm{Y})$ in this research is the multiple panel data regression analysis.

$\begin{array}{ll}Y=\beta 0+\beta 1 X 1 i t+\beta 2 X 2 i t+\varepsilon Y \\ \mathrm{Y}= & \text { Firm Value } \\ \beta 1-\beta 2= & \text { Coefficient of Regression } \\ \beta 0= & \text { Constant } \\ \mathrm{X} 1 \mathrm{it}= & \text { Capital Structure } \\ \varepsilon \quad= & \text { Error Component } \\ \mathrm{X} 2 \text { it }= & \text { Firm Growth }\end{array}$

According to Basuki \& Prawoto (2016), the regression model estimation using panel data that can be performed through three approaches, among others: the data selection panel itself because in this study using a span of several years and also many companies. The first use of the time series data is intended for use in this study span of three years ie from 2013 to 2017. Then the use of the cross-section because research takes data from many companies (data pooled), the exact number of nine companies' sample. Given the panel data, is a combination of time series and crosssection, then to test the hypotheses that have been formulated in this study will be tested 
using regression. The regression model to determine whether it can be used or not as an analytical tool needs to be tested. Based Rohmana (2010: 241) the technical discussion panel data regression model estimation three techniques can be used are: (1) Models with OLS (Ordinary Least Square) or common effect; (2) Fixed effect model; (3) Model random effect. The variables investigated in this study are explained in table 5.

Table 5. Operationalization of Variables

\begin{tabular}{|c|c|c|c|c|}
\hline & Variable & Concept & Scale & Formula \\
\hline \multicolumn{5}{|c|}{ Dependent Variable } \\
\hline Y1 & $\begin{array}{l}\text { Price to Book Value } \\
\text { (PBV) }\end{array}$ & $\begin{array}{l}\text { The ratio of the price per } \\
\text { share and book value per } \\
\text { share }\end{array}$ & Ratio & $\begin{array}{c}\text { Market Price Per Share }- \text { Share } \\
\text { Book Value Per - Share } \\
\times 100 \%\end{array}$ \\
\hline \multicolumn{5}{|c|}{ Independent Variable } \\
\hline $\mathrm{X} 1$ & $\begin{array}{l}\text { Capital Structure } \\
\text { (DER) }\end{array}$ & $\begin{array}{l}\text { The ratio of total debt } \\
\text { held firm with total equity } \\
\text { of the firm }\end{array}$ & Ratio & $\frac{\text { Total Debt }}{\text { Total Equity }} \times 100 \%$ \\
\hline $\mathrm{X} 2$ & Firm Growth & $\begin{array}{l}\text { The difference between } \\
\text { total assets of the firm in } \\
\text { the current period to the } \\
\text { previous period against } \\
\text { the previous period total } \\
\text { assets }\end{array}$ & Ratio & $\begin{array}{c}\text { Total Assets }_{t}-\text { Total Assets }_{t-1} \\
\text { Total Assets }_{t-1} \\
\times 100 \%\end{array}$ \\
\hline
\end{tabular}

\section{Results}

This study uses panel data regression analysis techniques (incorporation of cross-section data and time series) using Eviews Software 9.0. In a panel data regression, three regression models can be used, i.e. a common model effect, fixed effect model and random effect models. In this study, there are two sub-structure that are the first to calculate the regression of capital structure variable towards the firm growth and the second is to calculate the regression of capital structure and firm growth towards the price to book value. In determining the regression model, two tests were conducted in determining a suitable model for this study, the chow test and the Hausman test. More details will be discussed in the following points.

\section{Chow Test}

Chow test or commonly called the F-test statistics is a statistical test that aims to choose whether it is better to use a model Pooled Least Squares or Fixed Effect. The test is done with the following hypothesis; $\mathrm{H} 0$ : the model of pooled least-square; H1: fixed-effect model. The test results chow test presented in the following table

Table 6. Chow Test Results (Substructure 1)

\begin{tabular}{llll}
\hline Effects Test & Statistics & df & Prob. \\
\hline $\begin{array}{l}\text { Cross-section } \\
\text { Chi-square }\end{array}$ & 1.289469 & 5 & 0.936 \\
\hline
\end{tabular}

Based on the output of the table above, it appears that the value prob. chi-square test for Chow is estimated at 0.936 . Because the value prob. chi-square $>0.05$, so it can be concluded that the model used is a common model effect. So for the first sub-structure followed by the Lagrange test to choose a model common effect or random effect is presented on the next point. 
Table 7. Chow Test Results (Substructure 2)

\begin{tabular}{llll}
\hline Effects Test & statistics & df & Prob. \\
\hline Cross-section Chi-square & 18.35384 & 5 & 0.0025 \\
\hline
\end{tabular}

Based on the output above table, it appears that the value prob. chi-square test for estimation Chow is 0.0025 . Because the value prob. chisquare $<0.05$, it can be concluded that the model

\section{Lagrange Test}

Lagrange test is used to determine whether the regression model using a common approach or used is the fixed effect model. So for the second sub-structure continued with Hausman test to choose the fixed effect model or random effect is presented on the next point.

Random Effect. With the help of Eviews 9.0 software obtained as follows:

Table 8. Lagrange Test Result (Sub Structure 1)

\begin{tabular}{ll}
\hline Test & Cross-section \\
\hline Breusch-Pagan & $\begin{array}{c}2.343112 \\
(-0.1258)\end{array}$ \\
\hline & \\
$\begin{array}{l}\text { The output on the table above shows that the } \\
\text { value prob. Breusch Pagan test for the } \\
\text { estimation amounted Lagrange } 0.1258 \text { because } \\
\text { the value prob. chi-square }>0.05, \text { it can be } \\
\text { concluded that the approach of using a common } \\
\text { effect. }\end{array}$ & $\begin{array}{l}\text { Hausman test is used to determine whether the } \\
\text { regression model approach uses the Fixed } \\
\text { Effect model or Random Effect model. With the } \\
\text { help of Eviews 9.0 software obtained as } \\
\text { follows: }\end{array}$
\end{tabular}

Table 9. Hausman Test Result ( Sub-Structure 2)

\begin{tabular}{cccc}
\hline Test Summary & Chi-Sq. statistics & Chi-Sq. df & Prob. \\
\hline Cross-section random & 0.473418 & 2 & 0.7892 \\
\hline
\end{tabular}

Based on the output table above shows that the value prob. chi-square test for estimation amounted Hausman 0.789; because the value prob. chi-square $>0.05$, it can be concluded that the approach of using a random effect.

Table 10. Panel Data Regression Analysis

\begin{tabular}{llll}
\hline Variable & Coefficient & t-Statistic & Prob. \\
\hline C & 0.884539 & 3.748362 & 0.0009 \\
DER & -0.118270 & -1.258664 & 0.2189 \\
CG & 0.237592 & 0.978184 & 0.3367 \\
\hline
\end{tabular}


Based on the table above, can be formulated panel data regression model equation that describes the influence of Capital Structure and Firm Growth to Price to Book Value, namely: $Y=0.885-0.118 X 1+0.238 X 2$

\section{Hypothesis Testing ( $F$ test and $t$-test)}

To determine whether or not there is a significant influence of the independent variables together on a dependent variable, $\mathrm{F}$ test or simultaneous test is conducted. In other words, would the two independent variables together were able to significantly influence the dependent variable. From the calculation, the value of Prob. F count equal to 0.336. Because of the value of Prob. F arithmetic (0.336)> 0.05, then $\mathrm{HO}$ is accepted. It can be concluded that simultaneous no significant influence of the variable Capital Structure (X1) and Firm Growth (X2) on the Price to Book Value (Y). T-test used $\mathrm{o}$ determine whether the independent variables had a significant or not a significant influence dependent variable partially. In this case, the independent variables consisted of two variables: Capital Structure and Firm Growth.

Hypothesis:

H01: b1 = 0Capital Structure (X1) does not affect the Price to Book Value) (Y).

Ha1: $b 1 \neq 0$ Capital Structure (X1) effect on Price to Book Value (Y).

H02: b2 = 0Firm Growth (X2) has no effect on Price to Book Value (Y).

Ha2: $b 2 \neq 0$ Firm Growth (X2) effect on Price to Book Value (Y).

Table 11. Hypothesis Testing (t-Test)

\begin{tabular}{llll}
\hline Variable & Coefficient & t-Statistic & Prob. \\
\hline C & 0.884539 & 3.748362 & 0.0009 \\
DER & -0.118270 & -1.258664 & 0.2189 \\
CG & 0.237592 & 0.978184 & 0.3367 \\
\hline
\end{tabular}

Partial assay performed to test the effect of independent variables on the dependent variable. In this study, the independent variables used are Capital Structure (X1), and Firm Growth (X2). The dependent variable used is the Price to Book Value (Y). Based on the partial test results obtained, Capital Structure (X1) does not have a significant effect on the Price to Book Value (Y). It can be seen from the value of the t-statistic -1.259 , that is smaller than $t$ table 2,052 with a negative direction of the relationship. Firm Growth does not have a significant effect on the Price to Book Value. It can be seen from the value of the $\mathrm{t}$-statistic 0.978 , and this value is smaller than $\mathrm{t}$ table 2,052 with the direction of a positive relationship. That also is in line with the probability value is above a tolerable error value is $5 \%(0.337>0.05)$ confidence level of 95\%, which means that the higher Firm Growth a firm will higher the Price to Book Value, but the effect was not significant.
A simultaneous test used to determine the influence of Capital Structure and Firm Growth together to Price to Book Value, using the coefficient of determination. A simultaneous test used to fatherly test the overall hypothesis, the coefficient of determination is used to calculate the effect of both the independent variable, the variable Capital Structure and Firm Growth. The effect interval ranged from 0 to 1 or $0 \%$ to $100 \%$. Table 4.9 below shows the results of the calculation of the coefficient of determination of 60 data used. Based on the output results Eviews 9.0 above, the value of R-squared of 0,078 , This suggests that the contribution of Capital Structure (X1) and Firm Growth (X2) on the Price to Book Value (Y) is $7.8 \%$ while other variables besides independent variables studied contribute the remaining $92.2 \%$.

According to Mutai (2014), firm growth is an indication of efficient deployment and use of capital and existing assets towards building financial strength and higher future earnings 
capacity in the medium to long term, and this is relevant to capital structure and as such financial leverage. In this research, the result shows that capital structure is contributing positively to firm growth, although the influence is insignificant. This result is in line with the research conducted by Anton (2016) which revealed the positive effect of leverage upon firm growth, where firms with higher leverage displayed rapid growth.

According to the Trade-off theory, if a firm's capital structure is above its optimal value, every increase of leverage will also decrease the firm value. The result shows that the Debt-to-Equity ratio is contributing negative influence to the Price-to-book value, contrary to this research's proposed hypothesis, although the influence is insignificant. This result is in line with the research conducted by Safrida (2008) on the impact of capital structure on firm's value. This may have to do with the risk that comes from using leverage, rather than minimize the underlying' risk, they increase it and influence the market share price to be more volatile. In addition to that, the increase in leverage also increases the firm risk and bankruptcy cost, resulting in a negative influence impact.

Meanwhile, the result also shows that there is a positive influence between firm growth and firm value, although the result is also insignificant. This result is in line with the research conducted by Sriwardany (2006) research found that the firm's growth has a direct and positive influence on stock price changes, which means that investors responded positively to information about their firm's growth, thus increasing the stock price.

As for the result, the Capital Structure relationship to the Firm Growth, according to the data shows that every increase of DER will change 0.071 of firm growth. DER share the same component with firm growth that is a total asset, so the increase in total asset contributes to the equity component of DER which shows when the total asset increase or decrease it will also impact the value of DER. This finding is also in line with research conducted by Anton (2016) which revealed the positive effect of leverage upon firm growth, where firms with higher leverage displayed more rapid growth. This is especially beneficial for a small firm that had just started as the cost of capital of debt is much cheaper than other funding sources. Thus it can promote rapid growth with the investment on a firm asset by utilizing debt.

DER has a negative relationship on the firm value can be explained by the increase of risk with the level of DER that exceeds the optimal value. The results show that in every marginal increase of DER will create a 0.118 change on the firm value. It shows that a firm with a high value of DER might be not a good choice for investment as it shows high risk with less purchase on stock will lower the market price per share as a component of PBV thus bringing down the overall firm value.

Data shows that the relationship between firm growth and firm value is positive, this can be seen as it has a value of 0.237 , which means that every one unit increase in firm growth creates 0.237 change in firm value. Firm growth positive relationship with firm value can be explained as growth in assets shows a good sign for the firm. It shows that the firm could generate more net income for more retained earning can be utilized to invest more in the asset in the firm. This would give a good signal for the investor which would increase the stock purchase and increase the market price per share and also increase the value of PBV.

\section{Conclusion}

Based on the results and analysis of panel data regression model for Capital Structure and Firm Growth influence towards Firm Value in Oil and Gas Companies period 2013-2017 with six firms as the research sample, it can be concluded that On the regression equation analysis, Capital Structure (DER) has a negative relation to Firm Value (PBV). It is supported by the T-test analysis, which shows that DER has no significant positive influence on PBV. However, the T-test result indicates the influence is not significant. For the Firm Growth relation to the Firm Value (PBV), the regression equation analysis shows that there is a positive relationship between the two variables. The fact is also supported by T-test results for Firm Growth to Firm Value (PBV) model which indicates there is a positive relation between Firm Growth and PBV. Although the result is not Significant. 


\section{References}

Abor, J. (2005). The effect of capital structure on profitability: an empirical analysis of listed firms in Ghana. The Journal of Risk Finance, 6(5), 438-445. https://doi.org/10.1108/152659405106 33505

Ang, J. S., Fatemi, A., \& Tourani-Rad, A. (1997). Capital structure and dividend policies of Indonesian firms. PacificBasin Finance Journal, 5(1), 87-103. https://doi.org/10.1016/S0927538X(96)00025-X

Apriyanti, C., \& Hamzah, M. Z. (2015). Pengaruh Kinerja Keuangan, Ukuran Perusahaan, Dan Struktur Aktiva Terhadap Struktur Modal perusahaan (Studi Kasus pada Perusahaan Manufaktur Sektor Industri Barang Konsumsi yang Terdaftar di BEI Tahun 2010-2015).

Aven, R. A. D., \& Press, F. (1994). The Frontiers of Excellence the follow-up to In Search Hypercompetition-Managing the Dynamics of StraSuccesful Change Strategies: Chief Executives in. International Management.

Campbell, G., \& Rogers, M. (2018). Capital structure volatility in Europe. International Review of Financial Analysis, 55, 128-139. https://doi.org/10.1016/j.irfa.2017.11.0 08

Devereux, M. P., Maffini, G., \& Xing, J. (2018). Corporate tax incentives and capital structure: New evidence from UK firm-level tax returns. Journal of Banking and Finance, 88, 250-266. https://doi.org/10.1016/j.jbankfin.2017 .12 .004

Dutu, R. (2016). Why has economic growth slowed down in Indonesia? An investigation into the Indonesian business cycle using an estimated DSGE model. Journal of Asian Economics, 45, 46-55. https://doi.org/10.1016/j.asieco.2016.0 6.003
ElBannan, M. A. (2017). Stock market liquidity, family ownership, and capital structure choices in an emerging country. Emerging Markets Review, 33, 201-231. https://doi.org/10.1016/j.ememar.2017 .11 .001

Fisk, J. M., \& Fisk, J. M. (2018). Oil and Gas in Ohio. The Fracking Debate, (May), 97-121.

https://doi.org/10.4324/978131521271 $5-5$

Gallup. (2014). Country Data Set Details. Country Data Set Details Gallup World Wide Research Data Collected from 2005 - 2014. 1-127.

Gitman, L. J. and C. J. Z. (2014). Principles of Managerial Finance 14th Edition. In Prentice Hall. https://doi.org/10.1016/08908389(89)90087-5

Hamidy, R. R., Wiksuana, I. G. B., Gede, L., \& Artini, S. (2015). Dengan Profitabilitas Sebagai Variabel Intervening Pada Perusahaan Properti Dan Real Estate Di Bursa Efek Indonesia Fakultas Ekonomi dan Bisnis Universitas Udayana ( Unud ), Bali , Indonesia Email: rahmanhamidy@gmail.com Tren investasi yang berkembang di. Jurnal Ekonomi Dan BIsnis Universitas Udayana, 10, 665-682. https://doi.org/ISSN : 2337-3067

Hoque, J., Hossain, A., \& Hossain, K. (2014). Impact of Capital Structure Policy on Value of the Firm - a Study on Some Selected Corporate Manufacturing Firms Under Dhaka Stock Exchange. Ecoforum, 3(2), 77-84.

Jensen, M. C., \& Meckling, W. H. (1976). Theory of the firm: Managerial behavior, agency costs and ownership structure. Journal of Financial Economics, 3(4), 305-360. https://doi.org/10.1016/0304405X(76)90026-X

Kakilli Acaravci, S. (2015). ***The Determinants of Capital Structure: Evidence from the Turkish Manufacturing Sector. International 
Journal of Economics and Financial Issues, 5(1), 158-171. https://doi.org/10.1108/AJEMS-112012-0072

Kotler, P., Keller, K. L., Brady, M., Goodman, M., \& Hansen, T. (2016). Marketing Management. https://doi.org/10.1016/00246301(90)90145-T

Kusumajaya, . (2011). "Pengaruh Struktur Modal Dan Pertumbuhan perusahaan terhadap profitabilitas dan nilai perusahaan pada perusahaan manufatur di Bursa Efek Indonesia". Denpasar : Program Pasca Sarjana Universitas Udayana. 1-132.

Lachmann, L. M. (1978). Capital and its structure. In Hospital topics (Vol. 89). https://doi.org/10.2307/2551636

Le, T. P. V., \& Phan, T. B. N. (2017). Capital structure and firm performance: Empirical evidence from a small transition country. Research in International Business and Finance, 42, 710-726. https://doi.org/10.1016/j.ribaf.2017.07. 012

LeBaron, D., \& Speidell, L. S. (1987). Why are the parts worth more than the sum? "Chop shop," a corporate valuation model. The Merger Boom: 79-95, 31, 78-101.

Martellini, L., Milhau, V., \& Tarelli, A. (2018). Capital structure decisions and the optimal design of corporate market debt prograams. Journal of Corporate Finance, 49, 141-167. https://doi.org/10.1016/j.jcorpfin.2017 .11 .011

McGuigan, J. R., Moyer, R. C., \& Harris, F. H. deb. (2011). Managerial Economics. In Cengage learning.

Nimalathasan, B., \& Ph.D, A. P. V. B. (2010). Capital Structure And Its Impact On Profitability: A Study Of Listed Manufacturing Companies In Sri Lanka. Revista Tinerilor Economisti (The Young Economists Journal),
1(15), $7-16$.

https://doi.org/10.4197/Eco.

Nurhikmah, D. (2013). Optimal Capital Structure Analysis a Study From Indonesia Telecommunication Companies Listed in Indonesia Stock Exchange Period 2009-2011. 2(1), 132.

Perusahaan, D. A. N. N. (2016). Pengaruh Struktur Modal Terhadap Produktivitas Aktiva, Kinerja Keuangan. (March).

Phusavat, K. (2013). Productivity Management in an Organization: Measurement and Analysis. In ToKnowPress. Retrieved from

http://ideas.repec.org/b/tkp/tkpmon/97 8-961-6914-05-5.html

Robichek, a, \& Myers, C. (1966). Problems in the Theory of Optimal Capital Structure. The Journal of Financial and Quantitative Analysis, 1(2), 1-35. https://doi.org/10.2307/2329989

Safrida, E. (2008). Eli Safrida: Pengaruh Struktur Modal Dan Pertumbuhan Perusahaan Terhadap Nilai Perusahaan Pada Perusahaan Manufaktur Di Bursa Efek Jakarta, 2008. USU e-Repository (C) 2008. Skripsi.

Shatravka. (2015). Wow: Working With Redmine. Some Journal, 1(1), 7. https://doi.org/726129

Sucuahi, W., \& Cambarihan, J. M. (2016). Influence of Profitability to the Firm Value of Diversified Companies in the Philippines. Accounting and Finance Research, 5(2). https://doi.org/10.5430/afr.v5n2p149

Swanson, Z., Srinidhi, B. N., \& Seetharaman, A. (2003). The Capital Structure Paradigm: Evolution of Debt/equity Choices. Retrieved from http://books.google.com/books?id=U0 ZWrqKLPG8C\&pgis=1

Syafruddin Ginting Sugihen: Pengaruh struktur modal terhadap produktivitas aktiva..., 2003 USU e-Repository (c) 2008. (2008). (2008). Syafruddin Ginting Sugihen: Pengaruh struktur modal 
terhadap produktivitas aktiva..., 2003 USU e-Repository @ 2008.

Varaiya, N., Kerin, R. A., \& Weeks, D. (1987). The relationship between growth, profitability, and firm value. Strategic Management Journal, 8(5), 487-497. https://doi.org/10.1002/smj.42500805

07

Vo, X. V., \& Ellis, C. (2017). An empirical investigation of capital structure and firm value in Vietnam. Finance Research Letters, 22, 90-94. https://doi.org/10.1016/j.frl.2016.10.0 14

Welch, I. (2011). Two common problems in capital structure research: The financial-debt-to-asset ratio and issuing activity versus leverage changes. International Review of Finance, 11(1), 1-17. https://doi.org/10.1111/j.14682443.2010.01125.x

Welch, I. (2011). Two common problems in capital structure research: The financial-debt-to-asset ratio and issuing activity versus leverage changes. International Review of Finance, 11(1), $1-17$. https://doi.org/10.1111/j.1468-

2443.2010.01125.x 